\title{
Peranan Ibu Rumah Tangga Terhadap Terciptanya Ruang Publik Di Kawasan Padat Penduduk Pattingalloang Makassar
}

\author{
Indah Sari Zulfiana ${ }^{*}$ \\ ${ }^{I}$ Program Studi Teknik Arsitektur Universitas Ichsan Gorontalo \\ *indahsarizulfiana@gmail.com
}

\begin{abstract}
Housewives on the densenly populated Pattingalloang inclined to conduct social interaction so as to create the common room that support their social activities. The research was conducted to obtain activity relations houswife in creating public space, that use of public space in support of their activities, and open of the sirculation seen from the results field observation. The qualitative methode done with the observation done by means of observation in the field of public space and the placement circulation users. So, in do interview on housewives activity. How close the relationship between the interanct are also observed to know reason the social interactin in each place. The result showed that public space deliberately created to accommodate social activities used in the maximum like eat together, nap, cook together and others. In addition, the match between the is one of an important reason to social interaction.
\end{abstract}

Keywords: housewives activity, public space, usage of space, space pattern

\begin{abstract}
Abstrak
Ibu rumah tangga pada kawasan permukiman padat penduduk Pattingalloang memiliki kecenderungan untuk berinteraksi sosial sehingga menciptakan ruang bersama yang dapat mendukung aktivitas sosialnya. Penelitian ini dilakukan untuk mengetahui hubungan aktivitas ibu-ibu dalam menciptakan ruang publik, pemanfaatan ruang publik tersebut untuk mendukung aktivitasnya serta hubungan kedekatan yang nampak dari pola sirkulasi yang terlihat dari hasil pengamatan lapangan. Metode kualitatif dilakukan dengan pengamatan langsung di lapangan terhadap ruang-ruang publik yang tercipta, penempatan serta alur sirkulasi dari setiap pengguna. Untuk itu, dilakukan wawancara tentang aktivitas-aktivitas ibu-ibu sebagai objek penelitian. Seberapa dekat hubungan antar pelaku yang berinteraksi juga diamati untuk mengetahui alasan-alasan terjadinya interaksi sosial pada masing-masing tempat. Hasil penelitian menunjukkan bahwa rata-rata ruang publik yang ada sengaja dibuat oleh ibu-ibu pada kawasan tersebut sebagai bagian dari ruang sosial yang dimanfaatkan secara maksimal tidak hanya menampung kegiatan sosial, tetapi juga mencakup kegiatan lain seperti makan bersama, tidur siang, masak bersama, dan lain sebagainya. Selain itu, alasan kecocokan antar penghuni merupakan salah satu alasan penting dalam melakukan interaksi sosial.
\end{abstract}

Kata kunci: aktivitas ibu rumah tangga, ruang publik, pemanfaatan ruang, pola ruang

\section{Pendahuluan}

Ruang publik merupakan suatu hal penting dalam suatu kawasan permukiman yang dapat menampung aktivitas sosial masyarakat. Ruang publik adalah tahap di mana drama kehidupan komunal terungkap, dimana ruang publik mendukung kegiatan yang berhubungan dengan kehidupan publik dan memberikan kebebasan terhadap setting baik dalam keluarga atau kelompok tertentu
[1]. Jadi ruang publik tercipta dan di desain sesuai dengan kebutuhan pemakai. Pada kawasan permukiman padat penduduk, ruang publik yang ada dimanfaatkan secara maksimal seperti jalan dan teras rumah, akibat lahan yang tersedia tidak memadai untuk terciptanya ruang publik baru. Kondisi seperti ini juga pernah terjadi pada abad pertengahan, dimana jalan-jalan kota yang khas, sempit dengan banyak kegunaan, sehingga terjadi 
konflik yang cukup besar antara masyarakat dan pemilik toko yang ingin berdagang di jalan tersebut.

Dengan kondisi seperti yang telah dipaparkan sebelumnya, mengakibatkan ruang-ruang publik yang tercipta sangat sederhana berupa bangku atau kursi dengan penempatan jarak yang cukup dekat satu dengan yang lainnya. Ruang publik sebagai ruang bersama dapat tercipta akibat adanya aktifitas yang berlangsung secara terusmenerus. Interaksi sosial yang stabil menjadi syarat terbentuknya ruang bersama. Apabila interaksi tidak stabil maka ruang akan terpecah dan sebagai konsekuensinya ruang bersama akan pecah [4].

Ruang bersama menekankan pada isi (interaksi) dari pada wadah (fisik ruangnya). Ruang sosial bersifat temporal yang berkaitan dengan waktu. Selain itu, penataan perabot juga harus diperhatikan. Jika psikologi lingkungan ingin menciptakan interaksi kelompok, maka ruangan perlu dirancang dalam konfigurasi sociopetal yaitu penataan perabot yang membuat orang ingin berkumpul. Teori ini menyatakan adanya penyebab perbedaan setting pada ruang bersama [2].

Penelitian ini bertujuan untuk mengetahui dasar pembentukan ruang bersama oleh ibu rumah tangga di kawasan permukiman padat penduduk Pattingalloang, mengetahui pemanfaatan ruang dengan mengukur pengaruh ruang terhadap kegiatannya, serta untuk mengetahui pola penggunaan ruang dan kecenderungan sosialisasi pada satu ruang.

\section{Metoda Penelitian}

Ibu rumah tangga sebagai orang yang memiliki waktu yang lebih banyak di rumah, memiliki andil yang besar terhadap penciptaan ruang publik. Hal ini dikarenakan perempuan berinteraksi pada jarak yang lebih dekat dengan perempuan lainnya. Penemuan ini merefleksikan sosialisasi perempuan lebih afliatif dan lebih berpengalaman dengan intimasi non verbal [2]. Hal tersebut memperjelas bahwa ibu-ibu memiliki waktu yang lebih banyak untuk berinteraksi. Teori aktifitas menyatakan bahwa jalan menuju penuaan yang sukses adalah dengan cara tetap aktif [4]. Teori ini mendukung aktifitas sosial ibu rumah tangga dengan terbentuknya ruang bersama.

Dengan adanya ruang bersama akibat aktifitas yang berlangsung, maka akan membentuk suatu pola tertentu. Adanya saling keterkaitan antara hubungan antara pengelompokan group sosial dengan lingkungan. Group sosial yang stabil akan terbentuk di ruang tertentu dan pola terbentuknya group sosial akan mengakibatkan pola penggunaan ruang pula [3].

\subsection{Lokasi Penelitian}

Lokasi penelitian berada di kawasan permukiman padat penduduk kelurahan Pattingalloang, kecamatan Ujung Tanah kota Makassar seperti ditunjukkan dalam Gambar 1.

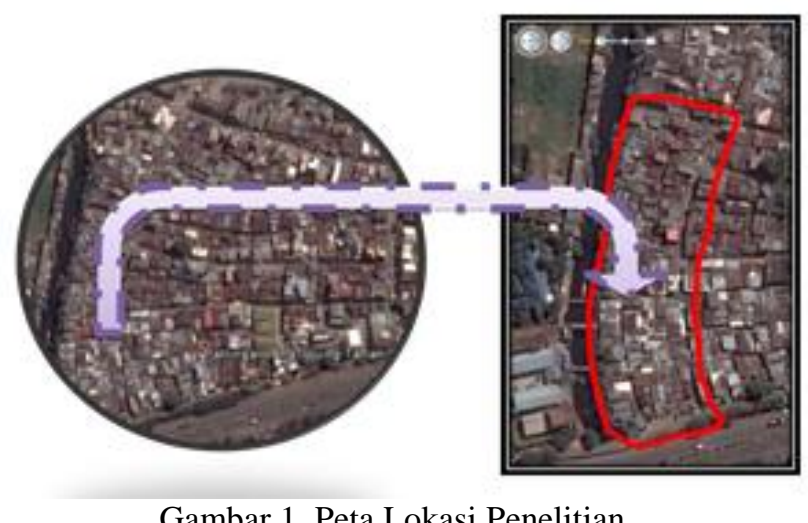

\subsection{Sampel}

Pengambilan sampel dengan menggunakan teknik non probability sampling dengan cara accidental sampling, dimana pengambilan objek wawancara dilakukan dengan menemui ibu-ibu yang sedang berkumpul pada ruang bersama yang telah terbentuk kemudian dilakukan wawancara sebanyak maksimal tiga orang. Teknik ini dipilih karena fokus penelitian yaitu ibu-ibu dan ruang bersama. 


\subsection{Pengumpulan Data}

Pengumpulan data dilakukan dengan cara observasi langsung ke lapangan dan melakukan wawancara terhadap ibu-ibu yang sedang berkumpul di lokasi penelitian. Sebelum ke lokasi, pertama-tama dilakukan cropping peta dengan menggunakan google earth kemudian dilakukan scanning lokasi awal untuk mengetahui titik-titik berkumpul ibu-ibu pada lokasi penelitian. Variabel yang digunakan yaitu:

1. Pelaku, yaitu aktivitas ibu-ibu;

2. Tempat, yaitu jalan linier dan jalan buntu;

3. Sarana, yaitu bangku, meja, dak beton dalam hal penataan dan ukuran;

4. Waktu, yaitu pagi, siang, sore.

\subsection{Analisis Data}

Setelah dilakukan pengumpulan data observasi dan wawancara di lapangan, maka selanjutnya dilakukan analisis data terhadap data-data yang telah dikumpulkan.

\section{Hasil Penelitian}

Hasil dari observasi di lapangan di dapatkan 8 spot yang akan di amati aktifitas dan pola ruang yang terbentuk seperti dalam Gambar 2.

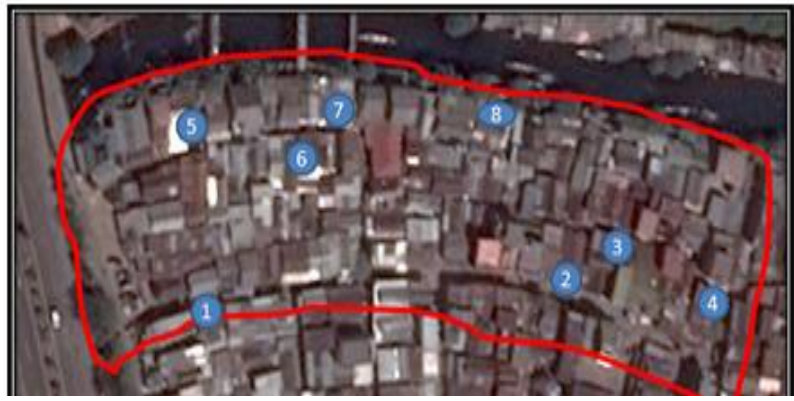

Gambar 2. Spot yang diamati

Adapun aktifitas dan pola pergerakan yang terbentuk ditunjukkan dalam Gambar 3 sampai dengan Gambar 18.

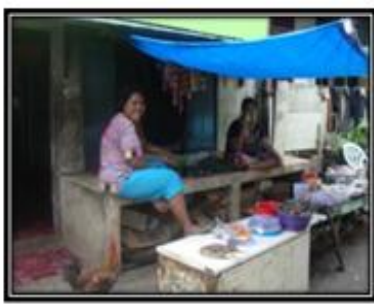

11.00SIANG

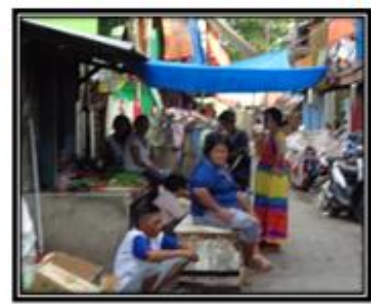

17.00SORE
Gambar 3. Aktivitas Ibu-ibu pada Spot 1
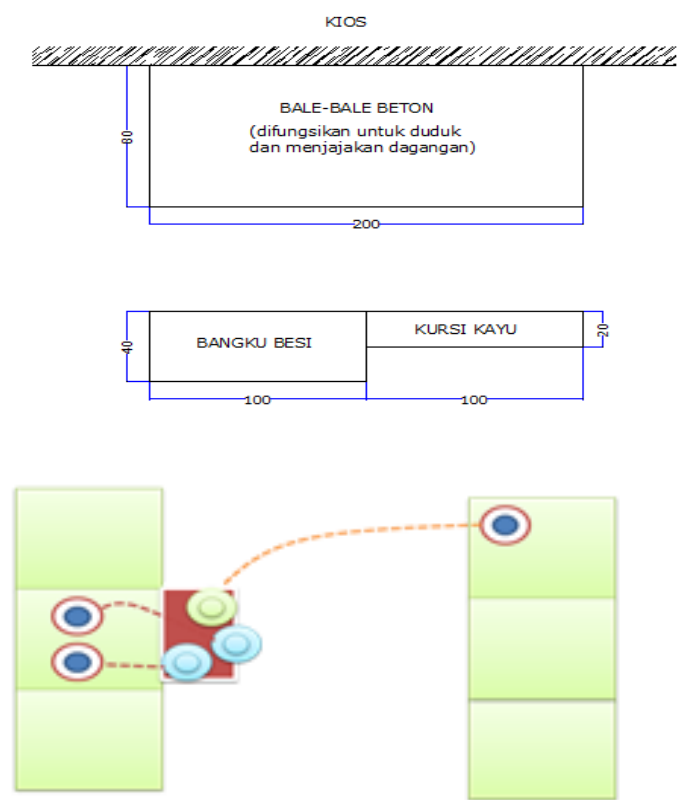

Gambar 4. Setting layout dan pola pergerakan spot 1

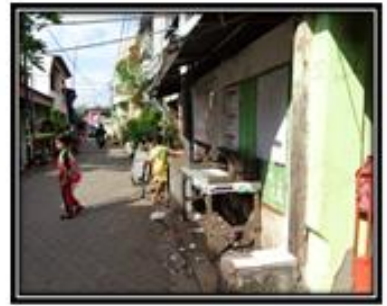

09.00 PAGI

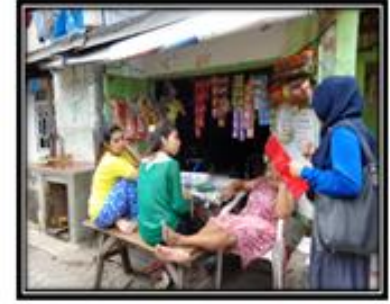

17.00SORE
Gambar 5.Aktivitas Ibu-ibu pada Spot 2.

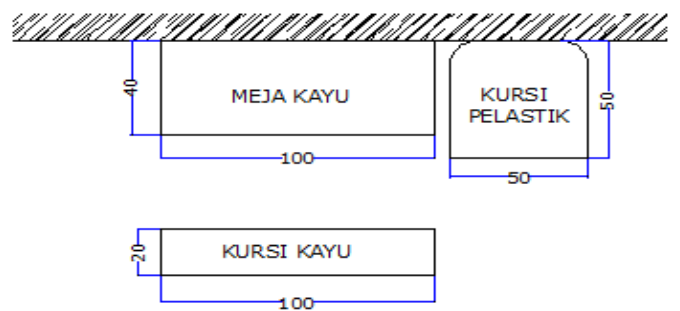




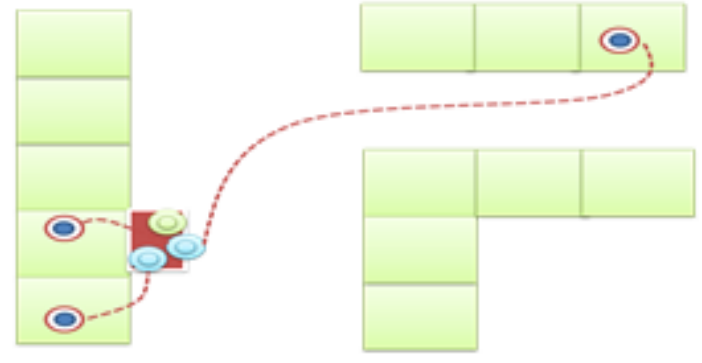

Gambar 6. Setting layout dan pola pergerakan spot 2

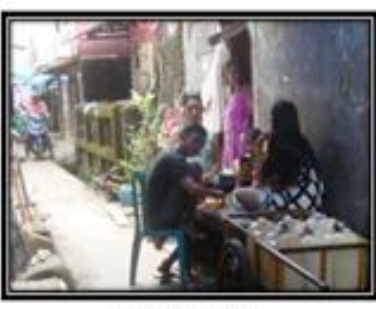

12.00 SIANG

Gambar 7. Aktivitas Ibu-ibu pada Spot 3

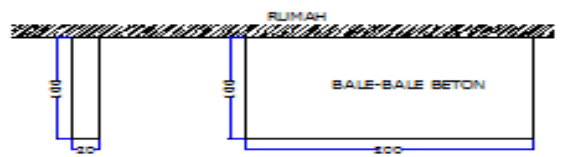

sacan
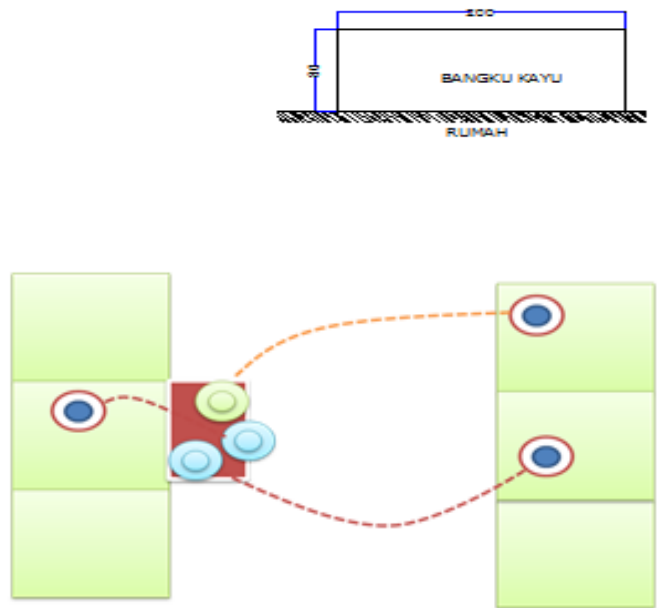

Gambar 8. Setting layout dan pola pergerakan spot 3

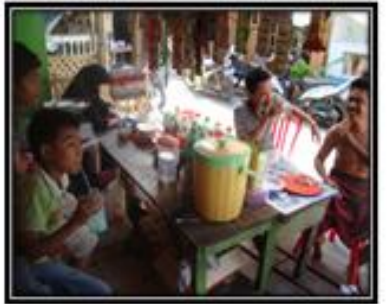

12.00 SIANG

Gambar 9. Aktivitas Ibu-ibu pada Spot 4
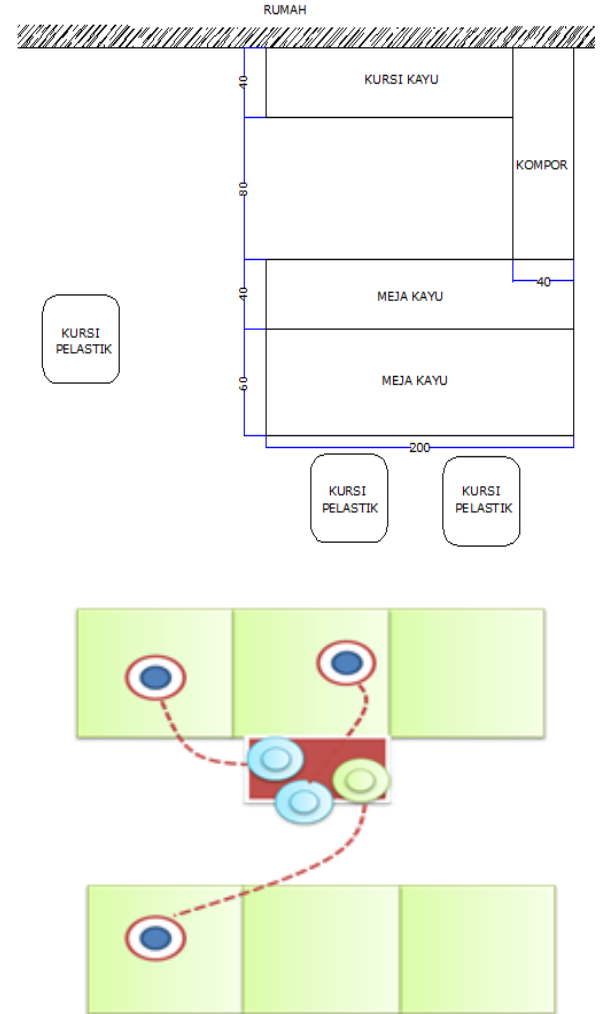

Gambar 10. Setting layout dan pola pergerakan spot 4

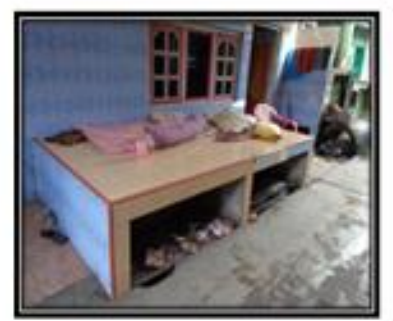

09.00 PAGI

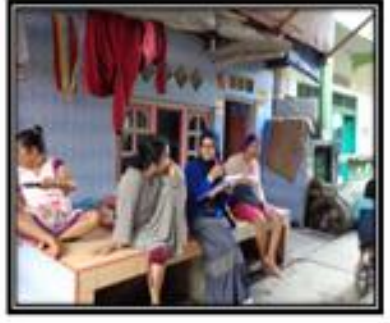

17.00 SORE
Gambar 11. Aktivitas Ibu-ibu pada Spot 5 

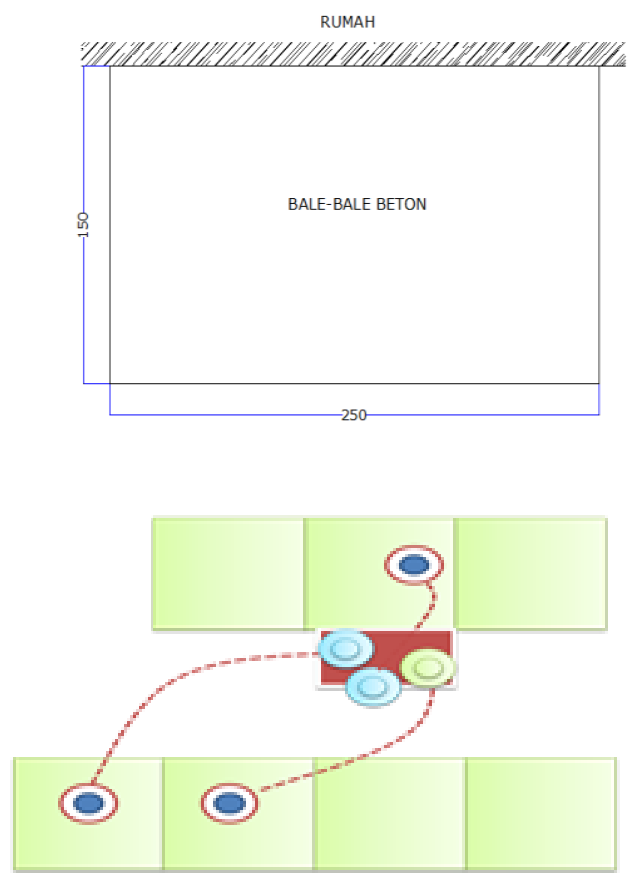

Gambar 12. Setting layout dan pola pergerakan spot 5

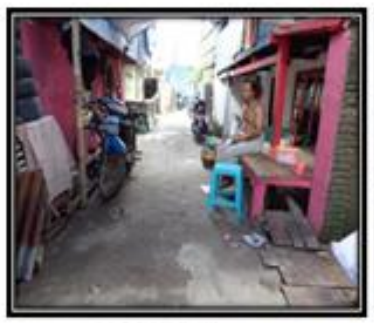

09.00 PAGI

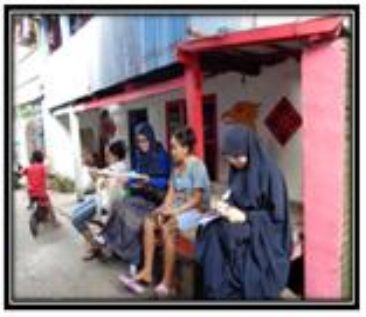

17.30 SORE
Gambar 13. Aktivitas Ibu-ibu pada Spot 6

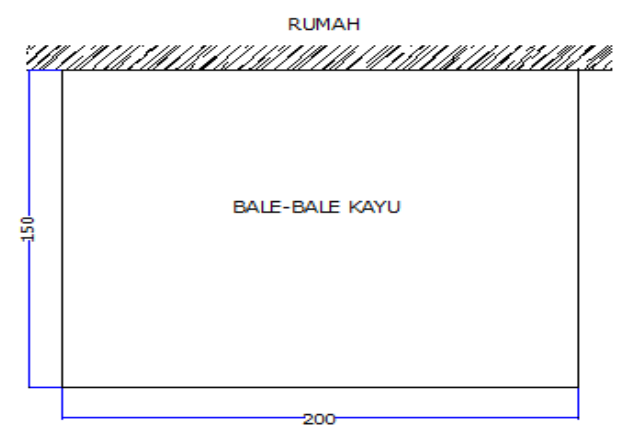

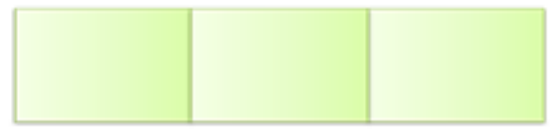

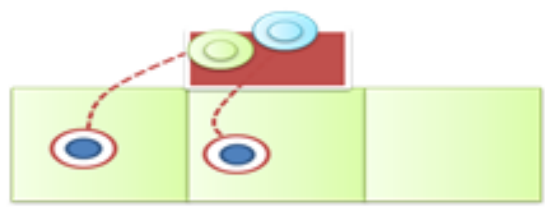

Gambar 14. Setting layout dan pola pergerakan spot 6

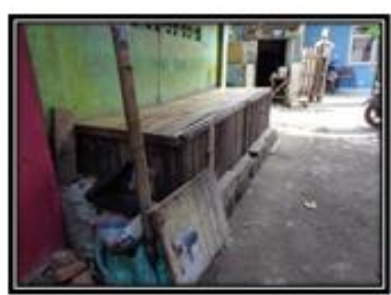

09.00 PAGI

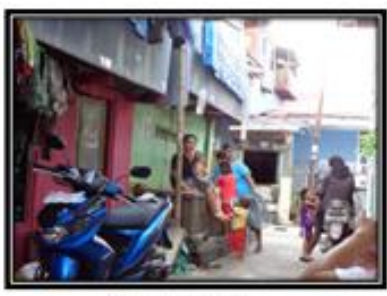

17.30 SORE
Gambar 15. Aktivitas Ibu-ibu pada Spot 7
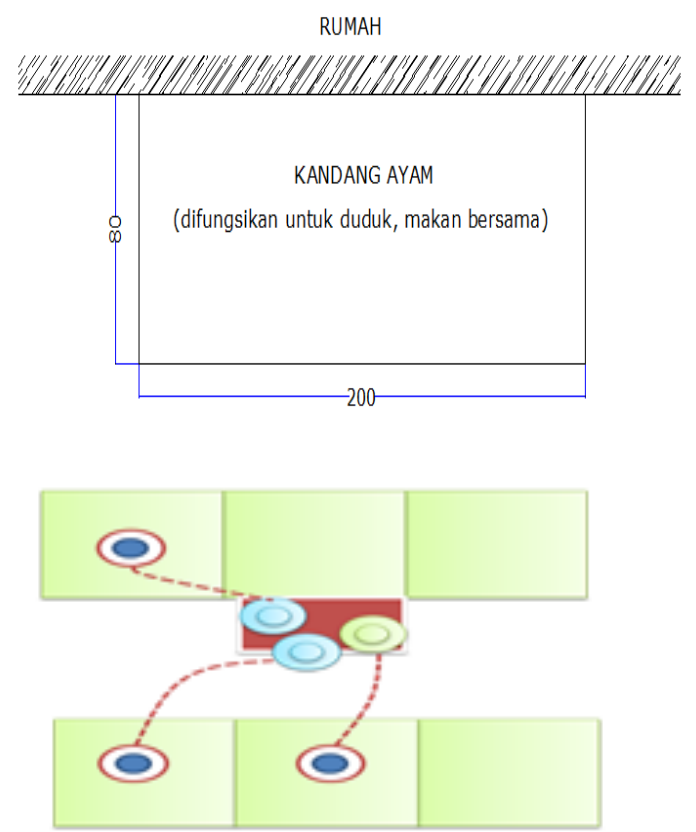

Gambar 16. Setting layout dan pola pergerakan spot 7 


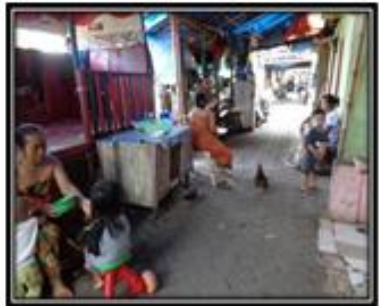

09.00 PAGI

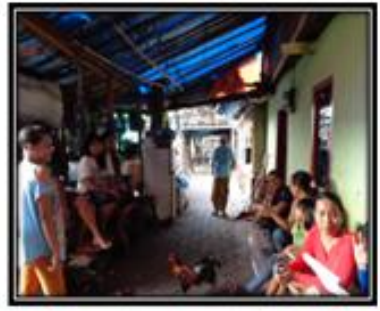

17.3OSORE
Gambar 17. Aktivitas Ibu-ibu pada Spot 8
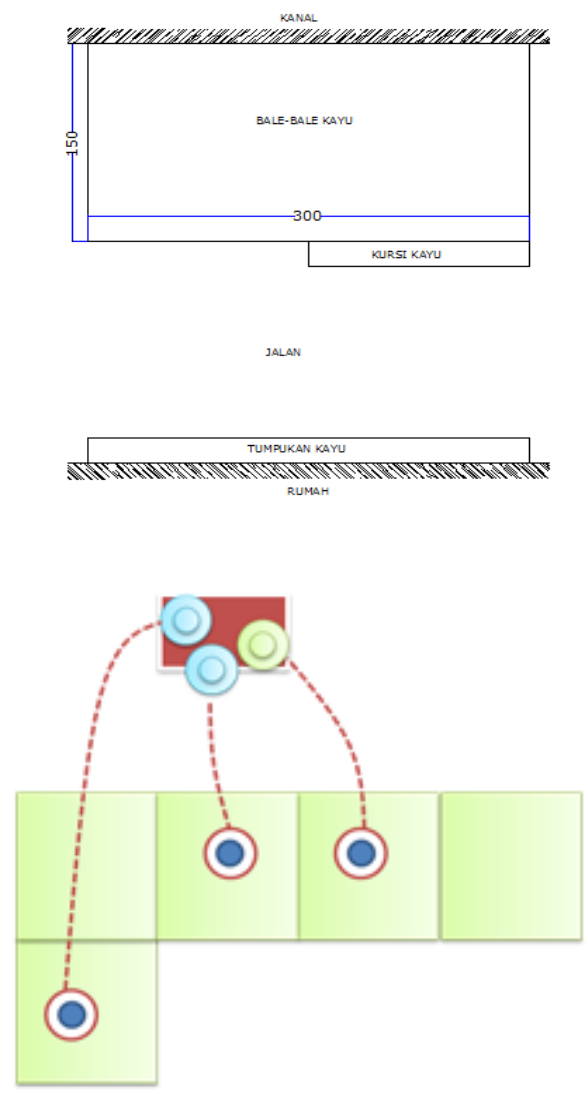

Gambar 18. Setting layout dan pola pergerakan spot 8

Dari analisis data yang telah dilakukan sebagai hasil dari observasi lapangan dan wawancara, maka dapat ditarik suatu pembahasan dari rumusan masalah yang muncul.

\subsection{Pembentukan Ruang Bersama}

Ruang bersama terbentuk akibat dari pekerjaan ibu-ibu pada umumnya merupakan ibu rumah tangga sehingga sebagian besar waktu dilakukan di rumah dan di sekitar tempat tinggal. Gambar 3, 5, 7, 9, 11, 13, dan
15 menunjukkan adanya aktivitas yang hampir sama pada sebagian besar ibu-ibu sehingga memiliki waktu dan alasan yang sama untuk berkumpul. Selain itu, pada Gambar 4, 6, 8, 10, 12, 14, dan 16 menunjukkan adanya jarak antar rumah yang begitu dekat atau saling berdempetan sehingga memungkinkan untuk melakukan aktivitas di luar rumah secara bersama.

\subsection{Pemanfaatan Ruang}

Pada jalan linier, kegiatan pada ruang publik terbatas pada aktivitas interaksi sosial berupa berdiskusi dan duduk-duduk serta ratarata ruang publik tersebut fungsi utamanya adalah warung, seperti dalam Gambar 1, 5,dan 9. Pada jalan setapak atau jalan buntu, kegiatan pada ruang publik berkembang sebagai tempat untuk makan bersama, beristirahat, tidur, masak bersama seperti dalam Gambar 7, 9, 11, 13, 15, dan 17. Hal ini dikarenakan kondisi pada jalan setapak atau jalan buntu dianggap tidak terlalu ramai oleh lalu lintas publik sehingga penghuni merasa nyaman melakukan aktivitas tersebut.Sebagian besar alasan berkumpul yaitu adanya kedekatan jarak tempat tinggal. Selain itu, faktor kekeluargaan dan kenyamanan juga berpengaruh besar terhadap alasan untuk berkumpul dikarenakan tidak semua manusia yang satu memiliki kecocokan dengan yang lainnya.

\subsection{Pola Pergerakan Ruang}

Sebagian besar alasan berkumpul yaitu adanya kedekatan jarak tempat tinggal.Selain itu, faktor kekeluargaan dan kenyamanan juga berpengaruh besar terhadap alasan untuk berkumpul. Sebagian besar masyarakat merasa nyaman berkumpul di tempat yang memiliki dimensi yang cukup besar seperti bale-bale, dibanding tempat berkumpul yang hanya menyediakan beberapa bangku untuk duduk seperti halnya di warung.

\section{Kesimpulan}

Berdasarkan hasil pembahasan, dapat ditarik kesimpulan bahwa pembentukan ruang 
bersama salah satunya akibat aktivitas ibu-ibu yang sebagian besar memiliki pekerjaan sebagai ibu rumah tangga yang menghabiskan hampir seluruh waktunya dirumah.

Setelah ruang bersama terbentuk, pemanfaatan dilakukan secara maksimal, tidak hanya digunakan untuk berdiskusi, tetapi lebih jauh lagi seperti makan bersama, masak bersama dan lain sebagainya.

Pola pergerakan terbentuk tidak hanya karena kedekatan jarak antar rumah tetapi juga karena faktor kecocokan satu dengan yang lainnya.

\section{Saran}

Objek serta waktu penelitian yang terbatas, mengakibatkan perlunya penelitian yang lebih lanjut agar hasil yang didapatkan dapat benar-benar akurat.

\section{Daftar Pustaka}

[1] C. Stephen et al., Public Space, Environment and Behavior Series. New York: Cambridge University Press, 1992.

[2] H. Deddy, Psikologi Arsitektur. Jakarta: PT. Gramedia Widiasarana Indonesia, 2005.

[3] L. J. Marcella, Arsitektur dan Perilaku Manusia. Jakarta: PT. Garasindo, Edisi Kedua, 2005.

[4] W. Mahendra. (2012, 16 Januari). Terbentuknya Ruang Bersama Oleh Lansia Berdasarkan Interaksi Sosial dan Pola Penggunaannya. Sidang Terbuka Promosi Doktor, Bidang arsitektur, Institut Teknologi Sepuluh November. Diambil dari http://digilib.its.ac.id 